\title{
The Point of Studying Ethics According to Kant
}

\section{LUCAS THORPE}

Philosophy Department, Faculty of Humanities and Letters, Bilkent University, Ankara,06800,Turkey; e-mail: lucas@bilkent.edu.tr

Many readers of Kant's ethical writings take him to be primarily concerned with offering guidelines for action. At the least, they write about Kant as if this were the purpose of his ethical writings. For example, Christine Korsgaard, in her influential article Kant's Analysis of Obligation: The Argument of Groundwork I, writes that, "the argument of Groundwork $I$ is an attempt to give what I call a 'motivational analysis' of the concept of a right action, in order to discover what that concept applies to, that is, which actions are right." Similar comments are not hard to find in the secondary literature. This, however, is a fundamentally misguided way of reading Kant, since he repeatedly asserts that we do not need to do moral philosophy in order to discover which actions are right. We already know how to behave morally and do not need philosophers to tell us this. "Common human reason," Kant argues, "knows very well how to distinguish in every case that comes up what is good and what is evil, what is in conformity to duty or contrary to duty." 2 Because people with pre-philosophical understanding know how to act morally, the purpose of moral philosophy cannot be to provide us with a set of rules for correct behavior. If we take Kant's claims about common human reason seriously, then his aim in the Groundwork of the Metaphysics of Morals cannot be to discover which actions are right.

It is instructive on this point to compare Kant's conception of moral philosophy with Christian Wolff's. Wolff's ethics was dominant in Germany during Kant's philosophical development, and Kant himself based his ethics lectures on a textbook written by one of Wolff's followers, Alexander Baumgarten. Unlike Kant, Wolff is an intellectualist who believes that there is no gap between recognizing an act as good and the act of willing it, He therefore believes that immoral behavior is always the result of mistaken beliefs about goodness. Thus, he can claim; "The knowledge of good is a motive of the will.... It cannot happen the one does not will an inherently good act if one distinctly conceives it ... So if 
we do not will [such acts], there is no other cause than that we do not recognize them" as good. ${ }^{3}$

If we knew what was good for us, we would do whatever was good for us. As a result of this, Wolff maintains that the only way we can become better human beings is by improving our knowledge of goodness, Unfortunately, discovering the truth about goodness is an arduous task, and Wolff is concerned that "perhaps someone will wonder how it will go with the pursuit of good and the omission of bad if so much is required in order to distinguish good from bad." 4 His response is to suggest a division of labor. It is not necessary that all people spend time putting in the work to distinguish the good from the bad; this job can be left to the philosophers. Thus Wolff explains that he is not just concerned with the discoverers of moral truths, for, "it is not necessary that all men be discoverers. It is enough if some among the learned devote themselves to discovery, whose findings the others can afterwards learn, which is much easier." 5

According to Wolff, then, the function of a moral philosopher is to discover the truth about good and bad and to communicate this truth to people who do not have the time, inclination or capacity to think about such matters. Wolff claims that this is the primary reason he writes his ethical works. Thus, he explains: "Because not everyone is skilled in discovery, ...those to whom God has lent the strength and opportunity to carry out this work better than others are obligated to share in books for the others what they have learned about the soul." 6 The function of moral philosophers is, from this perspective, to communicate moral knowledge to people who are ignorant so that they can lead more virtuous lives.

Kant, in contrast, has far more respect for the moral capacities of common men and women, and as a result of this he believes that there is "no need of science and philosophy to know what one has to do to be honest and good, and even wise and virtuous." If, however, we do not need moral philosophy to know what we must do in order to be good, we may might question what the point of moral philosophy is. Kant himself believes that moral inquiry is not a purely theoretical exercise but that it does have some practical value, and any serious interpretation of Kant's ethics must take this into account. Before examining Kant's account of this role, however, we will first make a few remarks about the content of Kant's moral philosophy. What is said here is intended to make the need for an account of the value of moral philosophy even more urgent since, as we shall see, Kant, like Wolff, believes that moral philosophers attempt to provide us with a clearer understanding of goodness. However, unlike Wolff, he does not believe that this increase in clarity will of itself make us better human beings. 


\section{Moral Idealism}

Instead of attempting to discover which actions are right, Kant's primary aim in the Groundwork of the Metaphysics of Morals is to explain what it is that a virtuous human being motivated by duty is striving to be. $\mathrm{He}$ begins by examining the moral consciousness of pre-philosophical individuals. Such individuals know how to be moral and have an obscure grasp of what it is to be moral, in that they have some idea of what it is to be a good person. Kant names such an idea an ideal, and believes that to have a moral conscience involves awareness of such an ideal which serves as a yardstick. Engaging in moral philosophy involves setting forth this idea in its full purity. Thus; in his ethics lectures from 1785 Kant explains: "to expound morality in its full purity is to set forth an Idea of practical reason. Such Ideas are not chimeras, for they constitute the guideline to which we must constantly approach.... We have to possess a yardstick by which to estimate our moral worth, and know the degree to which we are faulty and deficient. ... In the ideal we turn the ideas into a model." 8

This idea is an idea of pure reason, and as such it can be understood theoretically. For most of us, however, our theoretical understanding of this idea is obscure and the aim of the moral philosopher is to clarify our theoretical understanding of this ideal. This is Kant's aim in the Groundwork of the Metaphysics of Morals, where he refers to this ideal as the idea of a good will. Thus, at the start of section one, Kant explains his objective and strategy. He writes:

We have, then, to explicate the concept of a will that is to be esteemed in itself and that is good apart from any other purpose, as it already dwells in natural sound understanding and needs not so much to be taught as only to be clarified - this concept that always takes first place in estimating the total worth of our actions and constitutes the condition of all the rest. In order to do so, we shall set before ourselves the concept of duty, which contains that of a good will though under certain subjective limitations and hindrances, which, however, far from concealing it and making it unrecognizable, rather bring it out by contrast and make it shine forth all the more brightly. ${ }^{9}$

Here Kant makes it clear that we already possess the concept of a good will, that this concept dwells in natural sound understanding, and that what he proposes to do is to explicate and clarify this concept. At the end of section two, he reaches the conclusion that the concept of a good will is the idea of an autonomous member of a realm of ends. In claiming that 
the concept of a good will already dwells in natural sound understanding he means that this concept is a theoretical idea that can be understood theoretically. The concept of duty contains the concept of a good will because it is our duty to be a good will, and to fully understand the categorical imperative is to understand that it is our duty to strive to be a member of an ideal realm of ends. Kant's aim, then, cannot be to teach us this ideal, since it is an idea that we are already aware of, albeit obscurely. Instead, his aim is merely to explicate and clarify this concept. Kant is more explicit about this in the Metaphysics of Morals, where he writes that,

[N]o moral principle is based, as people sometimes suppose, on any feeling whatsoever. Any such principle is really an obscurely thought metaphysics. ... The way the teacher presents this (his technique) should not always be metaphysical nor his terms scholastic, unless he wants to train his pupil as a philosopher. But his thought must go all the way back to the elements of metaphysics, without which no certitude or purity can be expected in the doctrine of virtue, nor indeed any moving force. ${ }^{10}$

To teach ethics is to clarify an obscure metaphysics, and to do it philosophically involves doing it in scholastic terms. Although Kant's ultimate aim is to clarify the idea of a good will, he begins with an examination of the concept of duty, which will somehow help us in this task. Kant believes that the prephilosophical consciousness of duty is a subjective, felt consciousness of the moral ideal. The consciousness of duty or obligation is, however, a consciousness that has a certain idea as its object, namely the idea of being a member of a realm of ends. Thus, in order to clarify what is involved in this idea, Kant begins by examining our consciousness of duty, for it is an obscure consciousness of the idea.

For Kant, hearing the call of conscience is a bit like wanting to join a club or society. We can imagine the idea of an ideal society and decide that the most important thing in our life is to join it. The idea of such a society, to be an adequate idea, will include a conception of what the membership criteria are. However, although being moral is a bit like choosing to join a club, for a person with a pre-philosophical understanding of morality it is like choosing to join a society without being aware that this is what he is actually doing. The aim of moral philosophers is to provide us with greater clarity about what we are hoping to become when we listen to our conscience.

The following analogy might help to clarify this account of Kant's goal and strategy. A professor wants one of her students to join the American 
Philosophical Association and issues the following command: "Pay thirty-five dollars and sign here!" The student can understand and follow this order without really understanding what he has been ordered to do. The student is immediately aware that he has been ordered to sign a piece of paper. When the student realizes, perhaps after a discussion with a friend, that he has been ordered to join the American Philosophical Association, he has a clearer theoretical understanding of what he has just been ordered to do. A virtuous individual who listens to his conscience, and who only acts upon maxims that can be universalized is, so to speak, applying to join a realm of ends, possibly without understanding theoretically that this is what he has been ordered to do. Kant's goal in the Groundwork of the Metaphysics of Morals is to provide the common human understanding with such a theoretical understanding.

Instead of attempting to discover which actions are right, then, Kant's primary aim is to explain what it is that a virtuous human being, motivated by duty, is striving to be. He begins by examining the moral consciousness of a pre-philosophical individual. Such an individual recognizes that she should only act upon maxims that can be universalized because she implicitly recognizes the value of being an autonomous member of a realm of ends. Understood in metaphysical terms, the idea of a realm of ends is the idea of an intelligible world and Kant believes that each of us has the idea of an intelligible world and that our conscience implicitly demands that we strive to act in such a way that we can potentially be members of such a world. This is what Kant means when he claims in the Critique of Practical Reason that the moral law reveals an intelligible world to us. ${ }^{11}$ We do not, however, have to have a detailed theoretical understanding of what is involved in the idea of being a member of an intelligible world in order to act appropriately.

For Kant, a virtuous person is someone who listens to his conscience, and our conscience commands us to strive to be an autonomous member of a realm of ends. Our moral consciousness, then, involves an obscurely thought metaphysics and the role of a moral philosopher is to clarify the metaphysics. As we have already seen, however, Kant believes that we do not need to clarify the metaphysics in order to act correctly. In a passage from section one of the Groundwork of the Metaphysics of Morals, cited previously, Kant explains that he wishes to clarify our understanding of the concept of a good will so that it will "shine forth more brightly."12 This provides us with a clue for understanding the reason why Kant believes that engaging in moral philosophy has some practical value. The brighter something shines, the more noticeable it is, the harder it is to fail to pay attention to it. Engaging in moral philosophy, and clarifying the idea of a good will, helps us to pay attention to the moral ideal. It does 
this in two ways. In making the concept of a good will shine more brightly, it amplifies the volume of what Kant calls the judgment of conscience. Perhaps more importantly, it makes it harder for us to give ourselves excuses. Excuses are, Kant believes, like voices that compete with the voice of conscience for the attention of our will. This explains the practical value of engaging in moral philosophy.

\section{Intellectualism and Voluntarism}

To understand Kant's account of the role and value of moral philosophy it is necessary to understand his account of moral motivation and his explanation of the possibility of immorality. He wishes to steer a middle course between the Scylla of voluntarism and the Charybdis of intellectualism. An intellectualist maintains that the good is irresistible, because we always act under the aspect of the good. As a result of this, a intellectualist can claim that all immoral behavior is a result of not having a clear enough understanding of goodness. A voluntarist, in contrast, maintains that however clearly we understand what is good, we are always free to choose what is bad. Kant agrees with intellectualists that the good is irresistible. However, he also agrees with voluntarists that we are free to choose what is bad. In addition, he believes that all of us, possessing a conscience, have an adequate understanding of goodness. These commitments seem to be incompatible, since if our conscience provides us with an adequate understanding of what is involved in being good, and goodness is irresistible, it is not clear how, and in what sense, we can choose to be bad. Kant's solution is to argue, against intellectualists, that our consciousness of goodness is not directly through our intellects, but through our conscience.

The judgment of conscience is, Kant maintains, infallible and, in so far as we choose to listen to it, it is irresistible. As a result of this, if we were truly attentive to the voice of conscience we would always behave morally. We often, however, fail to pay attention to this voice. Kant believes that the failure is always the result of a free choice. In so far as we pay attention to the judgment of conscience, we will be virtuous. We are free, however, not to listen. This is the locus of our freedom of choice. The moral law, then, is like the Siren's voice. In so far as we choose to listen to it, it is irresistible. We are free, however, to plug our ears or to drown it out with competing voices.

This account of the locus of free choice helps us understand Kant's conception of the role of moral philosophers. As we have seen, Kant claims that his goal in the Groundwork is to clarify the concept of a good 
will. If Kant were an intellectualist, realizing this goal would serve an obvious moral function. An intellectualist believes that immoral behavior is always, and only, a failure to truly understand what is good, and so the clearer our understanding of what is good, the better we will be. Kant, however, is not an intellectualist. Indeed, he believes that even the prephilosophical human understanding has a good enough understanding of what is good to always act rightly.

\section{The Court of Conscience}

The primary role of a moral philosopher is to provide us with a tool that we can use to help ourselves pay attention to the judgment of conscience. For Kant, conscience is like an internal court that operates prior to and after our actions. Thus he explains in his ethics lectures that the conscience is a "consciousness of an internal court in a human being," one "before which his thoughts accuse or excuse one another." 13 This conscience is like a court and involves, "the assumption of an accuser, who seeks to arouse the conscience; a defender, who tries as an advocate to assuage it; and a judge, who assesses the action by the laws of duty and establishes the consequences."14

When we behave, or plan to behave, immorally, we fail to listen to the judgment of this court. This judgment, Kant believes, cannot err: the notion of "an erring conscience," he writes in the Metaphysics of Morals, "is an absurdity," and "if someone is aware that he has acted in accordance with his conscience, then as far as guilt or innocence is concerned nothing more can be required of him." 15 When we behave immorally, it is not that our conscience has erred. Nor is it the case that our conscience has failed to make a judgment, for the judgment of conscience is "an unavoidable fact." "Unconscientiousness," then, "is not lack of conscience but a propensity to pay no heed to its judgment."17 "So when it is said that a certain human being has no conscience, what is meant is that he pays no heed to its verdict."18 When we behave immorally, we attempt to give excuses to ourselves before this court for not living up to our moral ideal. We choose to listen to the defense attorney and try to block out the voice of the judge.

The voice of the judge of conscience is like the voice of a siren. In so far as we listen to it, it is irresistible. Kant calls the irresistibility of the voice of the judgment of conscience our moral predisposition. As a result of our predisposition to morality, Kant believes that we can only fail to be guided by the voice of our conscience if we stop up our ears or drown it out' with other voices. Thus, in the Religion within the Boundaries of Mere 
Reason, Kant argues that, "The human being (even the worst) does not repudiate the moral law, whatever his maxims, in rebellious attitude (be revoking obedience to it). The law rather imposes itself on him irresistibly, because of his moral predisposition; and if no other incentive were at work against it, he would also incorporate it into his supreme maxim as sufficient determination of his power of choice, i.e. he would be morally good." 19

The judgment of conscience is irresistible and, insofar as our inner ear is open, our faculty of desire will be determined by the law. Morality, for Kant, like the Stoic, is a matter of attentiveness, and immorality is the result of a, freely chosen, distraction. Engaging in moral philosophy helps us avoid distraction and in so doing it provides access to the law.

The purely intellectual activity of clarifying the idea of a good will does have some practical effect, since the clearer our theoretical understanding of the moral ideal, the more difficult it becomes for us to give ourselves excuses for not living up to it in practice. The reason for this is that the excuses we provide ourselves with in the court of conscience are themselves products of our intellect. Clarifying the concept of a good will can help us quiet the voice of the defense attorney in this court, and it is this voice that distracts our attention from the voice of the moral judge.

Kant believes, then, that although the moral ideal infallibly serves as a compass for our actions, and one that we all have always before our eyes, we often deliberately squint when we are taking directions. The moral philosopher cannot stop us squinting. She can, however, point out to us that we are squinting, which makes it more difficult for us to give excuses to ourselves if we choose to head in the wrong direction. The purpose of a moral philosopher, then, is to help us focus our attention on the moral ideal. Clarifying the moral ideal is to amplify the voice of the judge within, which is in danger of being drowned out by the pleading voice of the defense attorney in the court of conscience. Engaging in moral philosophy, then, can help us promote a particular duty, namely, "the duty to cultivate one's conscience, to sharpen one's attentiveness to the voice of the inner judge and to use every means to, obtain a hearing for it." 20

\section{An Analogy}

Kant believes that we all know what it is to do the right thing. Even the least educated peasant knows how to be moral. The judgment of 
conscience is the same for him as for an enlightened philosopher. This was a radical position to take in the eighteenth century. The problem with the philosophically uneducated is that they do not clearly grasp theoretically what it is to be moral. Their representation of what it is to be moral is obscure. In his logic lectures Kant explains the distinction between clarity and obscurity by comparing a suppossed savage, who sees a house from a distance but is not acquainted with its use, with a modern city dweller. Both have before them a representation of the same object however, "as to form, this cognition of one and the same object is different in the two. With one it is mere intuition, with the other it is intuition and concept at the same time. The difference in the form of the cognition rests on a condition that accompanies all cognition, on consciousness. If I am conscious of the representation, it is clear; if I am not conscious of it, obscure." ${ }^{21}$ To have an obscure representation, then, is to recognize an object without having an adequate concept of it. If we have an obscure representation of something, we can pick it out by pointing to it, but we are an able to give an adequate conceptual description. To introduce clarity is to provide such an adequate conceptual description.

Our obscure representation of what it is to be moral is a good enough guide to action, providing the common human understanding with its moral know-how. However, even though this obscure representation of the moral ideal is enough for us to know how to be moral, a clearer representation of this ideal does have practical value as it makes it more difficult to give ourselves excuses if we fail to live up to the ideal. Perhaps the following analogy can help us understand this value.

Let us imagine that we are going for a walk in the country with a friend. At one point we decide to split ways and our friend points to a building in the distance, a house on a hill, and tells us that he will meet us there in three hours. We vaguely make out something in the distance but it is too far away to make out what it is. We have an obscure representation of our goal, and we know that if we pay attention to where we are going we will have no problem finding our way there. If, however, we become distracted by the view, and stop paying attention to where we are heading and suddenly there are two hills in front of us, one with a house on top and one with a pub, we might, very easily, end up waiting for our friend in the pub. If our friend turns up after waiting in the rain outside the house on the other hill for three hours he will not be happy. We might tell him that we are sorry, but that he should not blame us or be angry with us because we honestly thought that we were in the right place, and in some sense it is true that we did not know that we were waiting in the wrong place. Trying to convince our friend, or ourselves, that we are entirely blameless, however, is in bad faith. It is true that we did not 
choose to make it our maxim to stand up our friend. If someone had come into the pub and told us that our friend was waiting outside in the rain, we would have jumped up and gone to find him. Our being in the wrong place, however, is willful in the sense that we chose not to pay attention to where we were going and our friend can legitimately be angry with us for having violated some ideal of friendship. If we had really cared about meeting him we would have paid attention to where we were going.

What Kant calls common human understanding has a similar relationship to the idea of a good will as the travelers have to the house on the hill. With common human understanding we know how to be moral just as the travelers know how to get to their meeting point. With common human understanding, however, we cannot really give an adequate description of what it is to be moral. This makes it easier for us to give ourselves excuses for failing to reach our moral destination. Kant's purpose in the Groundwork of the Metaphysics of Morals is to clarify what is involved in the idea of a good will, in order to have us understand what it is we are trying to be when we listen to our conscience. When we part ways he wants us to be able to say: "Let us meet outside that house with the green door over there." We can still end up waiting somewhere else, but if we have been given such explicit instructions it is much harder for us to give excuses to our friend, or to ourselves. If a friend has given us such clear instructions it will be much harder to convince him, or ourselves, that we honestly cared about the meeting if we end up in the wrong place.

This analogy helps us understand the role of a moral philosopher and teacher. The role of a moral teacher is not to tell us how to be moral. We already know that. The role of a moral educator is to make our obscure understanding of what it is to be moral shine out more brightly. This clearer understanding will not make us moral, but it will make it harder for us to listen to the excuses of the defense attorney in the court of conscience.

\section{Excuses}

To understand the way in which engaging in moral philosophy can help us avoid giving excuses, it is helpful to understand the types of excuses that we give ourselves when we behave badly. Kant suggests that there are two principal types of excuses we give ourselves when we act, or plan to act, immorally. Engaging in moral philosophy, makes it harder for us to give ourselves such excuses, because the excuses always have a basis in the intellect and thus can be combated by theoretical enquiry. 
The first type of excuse is a result of a willful corruption of our pure moral ideal. The second type of excuse involves willfully convincing ourselves that our moral ideal is impossible, either in itself or as an idea that can serve as an ideal for beings like us. This is despair.

Kant makes it clear that moral philosophers can play a major role in the fight against the corruption of our moral ideal. Thus Kant argues that "a metaphysics of morals is... indispensably necessary, not merely because of a motive to speculation, ... but also because morals themselves remain subject to all sorts of corruption as long as we are without that clue and supreme norm by which to appraise them correctly." 22 There are a number of ways our moral ideal can be corrupted. We can, for example, choose to be guided not by a pure ideal but by a watered down version. We do this, Kant believes, when we take happiness as our ideal. Happiness is an ideal, but, as Kant maintains in the Groundwork, it "is not an ideal of reason but the imagination." 23 Another case of the corruption of our ideal is when we take another particular individual as our ideal, comparing ourselves not to the pure idea of a good will, but with another, imperfect, human being, and taking the imperfect behaviour of that person as our standard. Choosing to imitate another person instead of taking the pure idea of an autonomous individual as our moral archetype, is one of the most common causes of excuses, and a form of excuse-giving that Kant is particularly worried about, since it allows us to excuse all sorts of behavior as excusably human. Thus in the ethics lectures he gave at the time he was working on the Groundwork, Kant explains that, "an example is when a general proposition of reason is exhibited in concreto in the given case. ... No examples are needed in matters of religion and morality. ... The examples, therefore, must be judged by moral rules, not morality and religion by the examples. The archetype lies in the understanding." 24

One of the targets of this attack is almost certainly the pietist culture around him. Perhaps the most popular genre of eighteenth century pietist literature were conversion narratives. In them, pietists told the stories of their own rebirths. Such narratives were extremely popular and were presented as models to be followed. Thus Johann Semler, a contemporary of Kant's, could write that, for the pietists "the story of ones own experience and edification became the rule for others to follow exactly.", 25

Kant believes that moral philosophers, in providing conceptual clarity about what is involved in our pure idea of a good will, make it easier for us to avoid the temptation of substituting the corrupted pseudo-ideal of happiness, or the behavior of others, for the pure idea of a good will.

Even if we are clear about what morality demands, Kant believes that we often willfully convince ourselves that it is impossible for us to live up 
to our moral ideal, either because we convince ourselves that the idea of an autonomous agent is itself impossible, or because we convince ourselves that it is impossible for us, as creatures with needs, to live up to such an ideal. There are two forms of despair. The first type of despair is the result of a recognition of our weakness as sensuous beings who have needs. When we give in to such despair, we tell ourselves that we have certain needs that it is physically impossible not to satisfy. The second type of despair is a result of the fact that we necessarily experience ourselves as phenomenal spatio-temporal, and hence conditioned, beings, whereas our moral ideal is an idea of pure reason, and as such it is the idea of a being that is unconditioned. When we give in to this form of despair we tell ourselves that it is logically impossible for a phenomenal being to be an autonomous individual.

A moral philosopher, Kant maintains, can help us avoid both forms of despair. She can help us avoid the first kind of despair by convincing us that it is not unreasonable to hope that there is a just and benevolent God who ensures that happiness is allocated in proportion to virtue. If we rigidly follow our duty, it is not unreasonable to hope that our needs will be met. She can help us avoid the second type of despair by convincing us that although we intuit ourselves as essentially causally determined conditioned beings, there is nothing contradictory in thinking of ourselves as autonomous, and hence unconditioned, individuals. A moral philosopher can do this by convincing us of the plausibility of transcendental, or formal, idealism. Proponents of formal idealism make a distinction between the form and matter of the objects of intuition, and claim that although the matter of the objects of intuition is real, the spatio-temporal form of the objects is ideal and subjective. If we accept transcendental idealism, we can think of objects of intuition, including ourselves, as unconditioned without contradiction. Although an object of experience cannot be thought of as unconditioned and simple qua object of experience, there is nothing contradictory in thinking of such an object as unconditioned and simple in itself.

\section{Conclusion}

Engaging in metaphysical speculation and working out clearly what is involved in the idea of being an intelligible world, and recognizing that there are no contradictions involved in it, cannot make us virtuous. To be virtuous, all we need to do is to listen to our conscience. Kant believes that grasping the idea of a good will in its purity is neither necessary nor sufficient for us actually to be good. Having grasped the idea in its purity, we are still faced with the choice of whether or not to recognize it as a 
practical ideal and to choose to strive to instantiate it. Grasping the idea in its purity, however, can make the choice to be good easier, or at the least, it makes it more difficult for us to give ourselves excuses for not living up to it. Thus, the conceptual clarity that arises as a result of engaging with traditional metaphysical questions about the nature of the intelligible world cannot provide us with knowledge, but it can help us avoid temptation and despair, It can help us avoid the temptation of replacing our pure idea with a corrupted, watered-down, impure, pseudoideal such as the ideal of happiness and it can help us avoid the despair of convincing ourselves that there is no such ideal or that it is impossible for us to live up to or instantiate such an ideal.

If this reading is correct, then, at its heart, Kant's ethics is surprisingly antinomian and particularist. Kant's rigorism is not basic to his ethics but is a result of the fact that we view ourselves through a glass darkly. Being good is not to follow a rule or a procedure but merely to listen to our conscience on a case by case basis. To be autonomous is not, primarily, to follow law, but to make law, and in true pietist spirit Kant believes that if we listen to our conscience, then our hearts will open and law will come pouring out. If we possessed moral self-knowledge there would be no need for moral rules and principles. However, we lack such self-knowledge and are prone to self-deception. We only know our empirical character and not our intelligible character or disposition. Our ultimate motivation remains obscure to us, and we never really know whether we are listening to the voice of the moral judge or that of the defense attorney. What stops Kant's ethics from being completely antinomian, and explains the function of moral philosophers, is his epistemic humility. We never know if we are really listening to our hearts, and in order to avoid self deception we must continually ask ourselves whether we really are making law or merely making excuses. Moral rules and principles are tools that we can use in this moral self examination, Moral Philosophers are not needed to tell us what to do, but they can help us determine whether we are living up to our own standards of morality. ${ }^{26}$

\section{Notes}

1. Christine Korsgaard, Creating the Kingdom of Ends (Cambridge, England: Cambridge University Press, 1996), p. 47.

2. Immanuel Kant, "Groundwork of the Metaphysics of Morals," in Immanuel Kant, Practical Philosophy, trans. Mary J. Gregor, ed.,(Cambridge, England: Cambridge University Press, 1996), p. 58; and Kants gesarmnelte Schriften, ed. Royal Prussian Academy of Sciences, 29 vols. (Berlin: de Gruyter, 1902), vol. 4, p. 404. 
3. Christian Wolff, "Reasonable Thoughts about the Actions of Men," in J. B. Schneewind, Moral Philosophy from Montaigne to Kant, (Cambridge, England: Cambridge University Press, 2003), p. 335.

4. Ibid., p. 341.

5. Ibid.

6. Ibid., p. 343.

7. Kant, Groundwork of the Metaphysics of Morals, p. 58; Ak 4: 404.

8. Kant, "Ethik Mrongoviusin" Immanuel Kant, Lectures on Ethics, Peter Heath and J. B. Schneewind, eds, (Cambridge, England: Cambridge University Press, 1997), p. 229; Ak 29: 604-605.

9. Kant, Groundwork of the Metaphysics of Morals, p. 52; Ak 4: 397.

10. Kant, "Metaphysics of Morals," in Practical Philosophy, p. 510; Ak 6: 376.

11. Kant, "Critique of Practical Reason," in Practical Philosophy, p. 215; Ak 5: 94.

12. Kant, Groundwork of the Metaphysics of Morals, p. 397; Ak 4: 397.

13. Kant, "Ethik Vigilantius," in Lectures on Ethics, p. 316; Ak 27: 618.

14. Ibid.

15. Kant, Metaphysics of Morals, p. 528-9; Ak 6: 401.

16. Ibid.

17. Ibid.

18. Ibid.

19. Kant, "Religion within the Boundaries of Mere Reason," in Immanuel Kant, Religion and Rational Theology, trans, Allen Wood and George di Giovanni, eds, (Cambridge, England: Cambridge University Press, 1996), p. 82; Ak 6: 36.

20. Kant, Metaphysics of Morals, p. 530; Ak 6: 401.

21. Kant: "Jäische Logic," in Immanuel Kant, Lectures on Logic, J. Michael Young, ed. (Cambridge, England: Cambridge University Press, 1992), pp. 544-545; Ak 9:33.

22. Kant, Groundwork of the Metaphysics of Morals, p. 45; Ak 4: 389-390.

23. Ibid., p. 71; Ak 4: 418.

24. Kant, "Ethik Collins," in Lectures on Ethics, p. 116; Ak 27: 332-333.

25. See Mary Fulbrook, Religion and the Rise of Absolutism in England, Württemberg and Prussia, (Cambridge, England: Cambridge University Press, 1983), p. 171.

26. I would like to thank Paul Guyer, Samuel Freeman, Karen Detlefsen, Shane Duarte, Myrna Gabbe, Berna Kilinç, llhan Inan, Andrea Rehberg, Geoff Bowe, and Kirsten Ward for comments on earlier drafts of this paper. I would particularly like to thank Thomas Magnell for his time and patience. 